\title{
Are There Levels of Students Morales? The Effects of Biological Problem Solving on Moral Development
}

\author{
Aminuddin Prahatama Putra ${ }^{1}$, Muslimin Ibrahim ${ }^{2}$, Huldani $^{3}$, Bayu Indra Sukmana ${ }^{4}$, Fauziah $^{5} \&$ Harun Achmad $^{6}$ \\ ${ }^{1}$ Biology Education Department, Faculty of Teacher Training and Education, Lambung Mangkurat University, \\ Banjarmasin, Indonesia \\ ${ }^{2}$ Faculty of Mathematic and IPA, Universitas Negeri Surabaya, Indonesia \\ ${ }^{3}$ Medical Sciences Department, Medical Faculty of Lambung Mangkurat University, Banjarmasin, Indonesia \\ ${ }^{4}$ Dentistry Department, Dentistry Medical Faculty of Lambung Mangkurat University, Banjarmasin, Indonesia \\ ${ }^{5}$ Medical Faculty of Lambung Mangkurat University, Banjarmasin, Indonesia \\ ${ }^{6}$ Department of Pediatric Dentistry, Faculty of Dentistry, Hasanuddin University, Makassar, South Sulawesi, \\ Indonesia \\ Correspondence: Harun Achmad, Department of Pediatric Dentistry, Faculty of Dentistry, Hasanuddin University, \\ Makassar, South Sulawesi, Indonesia. E-mail: harunachmader@gmail.com
}

Received: January 15, $2020 \quad$ Accepted: April 13, $2020 \quad$ Online Published: May 24, 2020

doi:10.5539/ies.v13n6p32 URL: https://doi.org/10.5539/ies.v13n6p32

\begin{abstract}
The implementation of the value of life and integrity has been done in the teaching and learning process of science by moral problems in life that relate to biological issues and to train the students' capability in problem-solving. It stimulated the students' moral development involving logic, feeling, and behaviors deemed as right and wrong in students. The purpose of this study is to describe the students' tiers of moral development through valid and reliable biological problem-solving. This study is descriptive research with a qualitative approach. The theoretical formulation formed is a design of the level of moral development about biological problems. The collection of data is done through a task-based interview. The subject of this research is students in the 8th grade of Banjarmasin Middle School. The data is analyzed using a constant comparison method. The results of this study indicate a valid and reliable level of students' moral development in solving biological problems. JPM2B1: An action is considered good from its principles and point of view to fulfill his/her obligations and needs without caring about other people's needs. Students often claim that "solving a problem is easy, it's because our teacher taught us to solve it". JPM2B2: An action is considered good from its perspective and principle of the movement for the greater good and planning a solution. JPM2B3: An action is considered good with a view of helping each other in creating a better future. JPM2B4: An action is considered good with a view of caring for the needs of others, emphasizing rational considerations for humanitarian reasons and God's blessing.
\end{abstract}

Keywords: student, morale, problem solving

\section{Introduction}

Science learning (including biology) has broad social and moral implications, implying that it is no longer morally free but rather bound to morals (Fraenkel, 1977). Science education has contributed to the training aspects of students' critical and objective thinking skills. Until now, with various changes, science education continues to instill values about honesty, discipline, appreciation of the meaning of humanity, caring, humility, protecting human life, and other values through learning activities carried out in schools (Ma-Kellams \& Blascovich, 2013). Biology, as part of the Natural Science, cannot be separated from matters related to God's authority and morals both to the environment and fellow human beings.

When learning biological science, teachers often try to ask students their opinions about various situations related to pollution, damage to natural resources, or the problem of epidemics in different regions. Others are situations involving conflict, socioeconomic inequality, infectious diseases, and drugs in multiple areas. Students at the basic education level can see the problem of injustice and sometimes can provide interesting solutions to the issues they face (Piaget \& Inhelder, 2010). Students, in particular, are very responsive to the problems of inequality that occur 
in their environment (Santrock, 2007). Familiarizing students with the ability to solve various problems concerning morals in daily life will lead to moral development in students. Moral development involves changes in reasoning, feeling, and behavior regarding what is deemed right and wrong. According to Santrock (2007), from a contemporary perspective, both negative and positive emotions contribute to moral development, including ethical behavior.

Morals adopted and believed by a person do not stay still but experience a stage of moral development (Sarbaini, 2011). Moral development is a change in reasoning, feeling, and behavior about standards regarding what is deemed right and wrong (Santrock, 2007; Upton, 2012). It's about how someone thoughts decide that something is good or bad (Slavin, 2009). One's moral reasoning reflects the difference in moral maturity (Budiningsih, 2008). According to Slavin (2009), if moral reasoning is seen as a structure, it can be said that there is a difference in the moral reasoning of a child with an adult, and this level of moral development can be identified. Santrock (2007) states that moral development occurs at a predictable level.

Piaget has argued that only in adolescence did formal operational, analytical thinking develops, Kohlberg also showed that during adolescence, the highest stage of moral development could be achieved, namely the principle of universal justice. This statement means that all stages of moral development expressed by Piaget and Kohlberg can be predicted, taught, and identified to students (Piaget \& Inhelder, 2010; Welch, 2011; Widodo \& Jatiningsih, 2013; Zuriah, 2011).

According to Zubaedi (2011), there are several skills needed for a student to practice the values adopted to behave constructively and morally in society. These skills include critical thinking, creative thinking, and problem-solving. According to BNSP (2006), the process of learning science (including biology) emphasizes the provision of direct experience to develop competencies to explore and understand the nature around scientifically.

Some experts and researchers have developed a general model to explain the problem-solving process (Foshay \& Kirkley, 2003; Polya, 1973; Tillman \& Cassone, 2012). The general pattern that is now widely adopted has three primary sequences in problem-solving, namely: (1) showing a problem (problem identification), (2) finding a solution (research of solution), and (3) implementing a solution (implementation of solution).

Problem-solving is a thought that is directly directed to find a solution to a specific problem (Duong, 2012). Wetzel (2008) states, problem-solving is the essence of scientific inquiry. Perry (2009) states that problem-solving is the art of thinking in its purest form.

The ability to solve problems related to one's moral consequences can generally be said to vary according to differences in personality, way of thinking, and behavior (Ma-Kellams \& Blascovich, 2013; Huitt, 1992; Myszkowski \& Storme, 2012; Huszczo \& Endres, 2013). Meanwhile, Dewiyani (2010), in her research, found the profile of each individual's thought process in solving problems turned out to be different.

Problem-solving referred to in this study is students learning in problem-solving from assignments related to the biological science materials taught by the teacher. The materials have a real-life context and presented in the form of discourse on moral dilemmas or intellectual conflicts (Fraenkel, 1977; Lind, 2005; Budiningsih, 2008). Based on the ground of moral dilemma, then students must identify the problem; identify possible solutions where students position themselves against the moral dilemma they face. Based on the results of students' problem-solving, we will see how students position themselves in the moral dilemmas they understand, the diversity of answers in the context of problem-solving, the novelty of their findings from the results of the analysis, and conclusions in the form of the authenticity of ideas made.

Based on the background of the research, the problems in this study are formulated as follows: "How is the valid and reliable level of students' moral development in solving biological problems?"

\section{Method}

\subsection{Research Type}

The stochastic theory formulated in this research is a scientific study that continues to develop. The data granted was obtained from what happened in the field, which was attended, accepted, and thought about by the students as research subjects. The description tracking of research data will be through interviews with tasks as explanatory morals and characteristics of moral development. This type of research is a descriptive study using qualitative research.

\subsection{Participant (Subject) Characteristics}

The subject of this research is students in the 8th grade of Banjarmasin Middle School 


\subsection{Research Procedures}

Diagram 1 is carried out as follows:

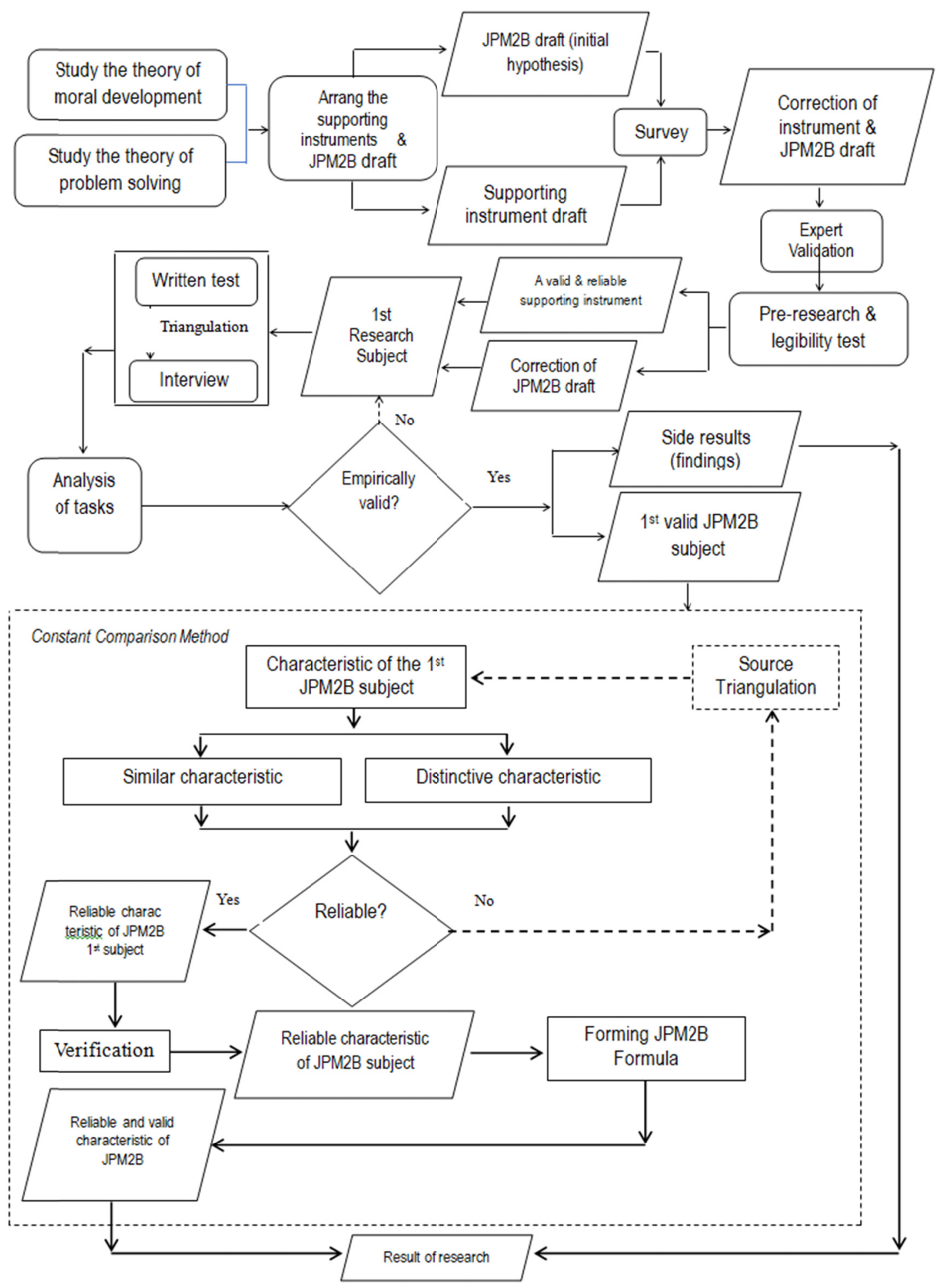

Diagram 1. Research procedure 


\section{Results}

3.1 Descriptions of Results of the Moral Development Levels of Students in Biological Problem Solving

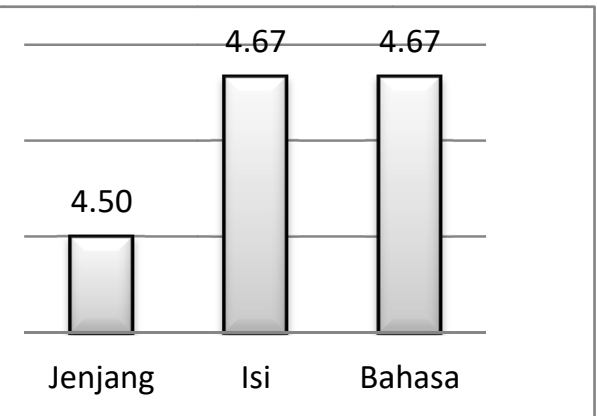

Chart 1. Result of JPM2B

Validation by Experts

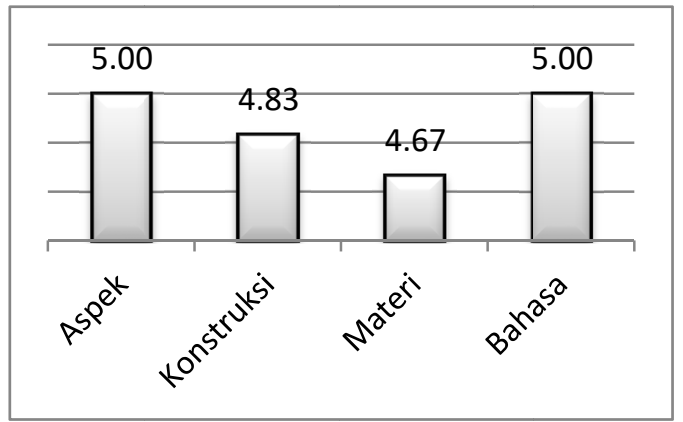

Chart 2. Result of Written Tasks

Validation by Experts

\subsection{Valid and Reliable Level of Moral Development Biological Problems}

\subsubsection{1st and 2nd Subject of JPM2B 1}

Comparative diagram of the hypothetical JPM2B 1 SU and LND subject as follows.

\begin{tabular}{|c|c|c|}
\hline $\begin{array}{l}\text { Corresponding } \\
\text { characteristics } \\
\text { (SU and LND) }\end{array}$ & $\begin{array}{l}\text { Other similar characteristics } \\
\text { (SU and LND) }\end{array}$ & $\begin{array}{l}\text { Other different characteristics } \\
\text { (SU and LND) }\end{array}$ \\
\hline 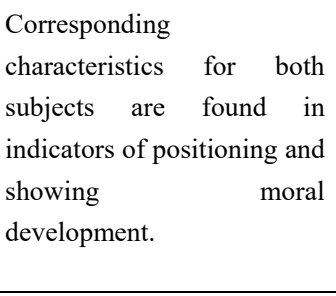 & $\begin{array}{l}\text { Both are not yet proper in } \\
\text { drafting a problem-solving, } \\
\text { problem-solving move, and } \\
\text { reassessing the results of } \\
\text { problem-solving. }\end{array}$ & $\begin{array}{l}\text { Characteristics of SU: } \\
\text { 1. The problem-solving plan is only made in } \\
\text { one position part either on task } 1 \text { or task } 2 \text {. } \\
\text { 2. Arguments or reasons underlying each step } \\
\text { in solving the problem are not made. } \\
\text { 3. A novel expression is made but incomplete } \\
\text { and unclear. }\end{array}$ \\
\hline & & $\begin{array}{l}\text { Characteristics of LND: } \\
\text { 1. Problem-solving plans are carried out in } \\
\text { both role positions, both task } 1 \text { or task } 2 \text {, even } \\
\text { though the steps are not correct. } \\
\text { 2. The arguments or reasons underlying each }\end{array}$ \\
\hline \multirow{2}{*}{\multicolumn{2}{|c|}{$\begin{array}{l}\text { Conclusion of the analysis: } \\
\text { 1. JPM2B } 1 \text { is reliable because SU and LND are at the same } \\
\text { level, so are the characteristics. } \\
\text { 2. Students view that moral actions are behaviors to meet } \\
\text { their own needs by manipulating others based on the } \\
\text { understanding of problems that can be solved without going } \\
\text { through planning, a step of completion, and rational } \\
\text { argument with no new expressions. }\end{array}$}} & $\begin{array}{l}\text { step in solving the problem are made, but } \\
\text { only in parts. } \\
\text { 3. A novel expression is created but has no } \\
\text { difference from the previous answer. }\end{array}$ \\
\hline & & \\
\hline
\end{tabular}




\subsubsection{3rd and 4th Subject of JPM2B 2}

\begin{tabular}{|c|c|c|}
\hline $\begin{array}{l}\text { Corresponding } \\
\text { characteristics } \\
(\mathrm{MHq} \text { and } \mathrm{NR})\end{array}$ & $\begin{array}{l}\text { Other similar characteristics } \\
\qquad(\mathrm{MHq} \text { and } \mathrm{NR})\end{array}$ & $\begin{array}{l}\text { Other different characteristics } \\
\text { (SU and LND) }\end{array}$ \\
\hline $\begin{array}{l}\text { Corresponding } \\
\text { characteristics of positioning } \\
\text { indicator on MHq and NR in } \\
\text { task } 2 \text { of the written answers }\end{array}$ & $\begin{array}{l}\text { Both are not yet proper in } \\
\text { making various } \\
\text { problem-solving designs and } \\
\text { in choosing the best reason } \\
\text { that shows moral } \\
\text { development, and it is not } \\
\text { applicable to show novelty. }\end{array}$ & $\begin{array}{l}\text { Characteristics of MHq: } \\
\text { 1. It is appropriate for the indicator to position } \\
\text { what should and should not be done in task } 2 \\
\text { 2. The problem identification made from the } \\
\text { two tasks is in accordance with the problem. } \\
\text { 3. The design of problem-solving in the steps } \\
\text { is correct and clear only in Task } 1 .\end{array}$ \\
\hline \multicolumn{2}{|c|}{$\checkmark$} & \multirow[b]{2}{*}{$\begin{array}{l}\text { Characteristics of NR: } \\
\text { 1. It is appropriate for the indicator to position } \\
\text { what should and should not be done in task } 1 . \\
\text { 2. The problem identification made is in } \\
\text { accordance with the problem. } \\
\text { 3. The plan for solving the problem is unclear } \\
\text { and incorrect. }\end{array}$} \\
\hline \multirow{3}{*}{\multicolumn{2}{|c|}{$\begin{array}{l}\text { Conclusions of the analysis: } \\
\text { 1. JPM2B } 2 \text { is reliable because MHq and NR are at the same } \\
\text { level, so are the characteristics. } \\
\text { 2. Students view that a person's behavior is always directed } \\
\text { to meet their own needs by using others. The principle of } \\
\text { their actions is interpreted physically and pragmatically, such } \\
\text { as "you do good to me, and I will also do good to you." } \\
\text { Students can understand the problem according to its } \\
\text { position, but can not plan to solve a problem, and do not carry } \\
\text { out problem-solving. }\end{array}$}} & \\
\hline & & \\
\hline & & Other discoveries \\
\hline
\end{tabular}

\subsubsection{5th and 6th Subject of JPM2B 3}

\begin{tabular}{|c|c|c|}
\hline $\begin{array}{l}\text { Corresponding } \\
\text { characteristics } \\
\text { (ASW and AR) }\end{array}$ & $\begin{array}{l}\text { Other similar } \\
\text { characteristics } \\
\text { (ASW and AR) }\end{array}$ & \\
\hline $\begin{array}{l}\text { Corresponding } \\
\text { characteristics of positioning } \\
\text { indicator on ASW and AR in } \\
\text { task } 2 \text { of the written answers }\end{array}$ & $\begin{array}{l}\text { Both are not yet proper in } \\
\text { making various } \\
\text { problem-solving designs } \\
\text { and in choosing the best } \\
\text { reason that shows moral } \\
\text { development, and it is not } \\
\text { applicable to show } \\
\text { novelty. }\end{array}$ & $\begin{array}{l}\text { Characteristics of ASW: } \\
\text { 1. Not appropriate for positioning indicators } \\
\text { that should and shouldn't be done in task } 1 \text {. } \\
2 \text {. The problem identification made from the } \\
\text { two tasks is in accordance with the problem. } \\
\text { 3. The design of problem-solving in task } 1 \text { is } \\
\text { correct and clear }\end{array}$ \\
\hline \multicolumn{2}{|c|}{15} & \multirow[b]{2}{*}{$\begin{array}{l}\text { Characteristics of AR: } \\
\text { 1. It is appropriate for the indicator to position } \\
\text { what should and should not be done in task } 1 . \\
\text { 2. The problem identification made is not in } \\
\text { accordance with the problem. } \\
\text { 3. The design of problem-solving is unclear and } \\
\text { incorrect. }\end{array}$} \\
\hline \multirow{3}{*}{\multicolumn{2}{|c|}{$\begin{array}{l}\text { Conclusion of the analysis: } \\
\text { 1. JPM2B } 3 \text { is reliable because ASW and AR are at the } \\
\text { same level, so are its characteristics. } \\
2 \text {. Students view that a person's behavior is always directed } \\
\text { to meet their own needs by using others. The principle of } \\
\text { his actions is interpreted physically and pragmatically, } \\
\text { such as "you scratched my back, and I will scratch yours." } \\
\text { Students can understand the problem according to its } \\
\text { position, but cannot plan to solve a problem, and do not } \\
\text { carry out problem-solving. }\end{array}$}} & \\
\hline & & \\
\hline & & \\
\hline
\end{tabular}




\subsubsection{7th and 8th Subject of JPM2B 4}

\begin{tabular}{|c|c|c|}
\hline $\begin{array}{l}\text { Corresponding characteristics } \\
\text { (IM and MNM) }\end{array}$ & $\begin{array}{l}\text { Other similar characteristics } \\
\text { (IM and MNM) }\end{array}$ & $\begin{array}{l}\text { Other different characteristics } \\
\text { (IM and MNM) }\end{array}$ \\
\hline $\begin{array}{l}\text { Corresponding characteristics of } \\
\text { positioning, diversity, and } \\
\text { novelty indicators in tasks } 1 \text { and } \\
2 \text { of the written answers }\end{array}$ & $\begin{array}{l}\text { Both have proper } \\
\text { understanding in the } \\
\text { problem, making a plan, } \\
\text { solving the problem, and } \\
\text { reviewing the solution, } \\
\text { which shows a moral view } \\
\text { on the applicable provisions. }\end{array}$ & $\begin{array}{l}\text { Characteristics of IM: } \\
\text { 1. It is appropriate for the indicators to } \\
\text { position what should and should not be } \\
\text { done in task } 1 \text { and task } 2 \text {. } \\
\text { 2. The problem identification made from } \\
\text { the two tasks is in accordance with the } \\
\text { problem. } \\
\text { 3. The design of problem-solving in task } \\
1 \text { is correct and clear. }\end{array}$ \\
\hline & & Characteristics of MNM: \\
\hline \multirow{3}{*}{\multicolumn{2}{|c|}{$\begin{array}{l}\text { Conclusions of the analysis: } \\
\text { 1. JPM2B } 4 \text { is reliable because IM and MNM are at the same } \\
\text { level, so are the characteristics. } \\
\text { 2. Students can put forward new expressions that are different } \\
\text { from previous statements with a moral view of maintaining social } \\
\text { order and applicable laws. Students can understand problems } \\
\text { according to their position, can plan to solve a problem with a } \\
\text { variety of roles, and can carry out problem-solving to produce } \\
\text { novelty. }\end{array}$}} & $\begin{array}{l}\text { 1. It is appropriate for the indicator to } \\
\text { position what should and should not be } \\
\text { done in task } 1 . \\
\text { 2. The problem identification made is in } \\
\text { accordance with the problem. } \\
\text { 3. The plan for solving the problem is } \\
\text { unclear and incorrect. }\end{array}$ \\
\hline & & \\
\hline & & Other discoveries \\
\hline
\end{tabular}

According to the previous analysis, following are the reliable JPM2B obtained:

\begin{tabular}{ll}
\hline JPM2B & Characteristic \\
\hline & A good act is judged by the views and principles of its actions to fill its obligations and needs regardless of \\
the needs of others, can formulate problems, and plan problem solving according to their role based on \\
biological material. Students tend to claim solving the problems quickly because the teacher has taught them, \\
but cannot solve diverse problems, and there are no new expressions.
\end{tabular}




\subsection{Characteristics Result of Moral Development Grading on Biological Problem}

A summary of the characteristics of students' moral development (SU and LND) residing in JPM2B1 is as follows.

\begin{tabular}{|c|c|c|c|}
\hline Characteristics & Positioning & Diversity & Novelty \\
\hline SU & $\begin{array}{l}\text { Connecting problems based } \\
\text { on biological materials he } \\
\text { has learned. An action is } \\
\text { considered good if it serves } \\
\text { to meet their own needs. }\end{array}$ & $\begin{array}{l}\text { Understanding: } \\
\text { Understands what is asked but not knowing } \\
\text { the other side of the question } \\
\text { Solution planning: } \\
\text { Not yet able to make a plan for solving the } \\
\text { problem that comes from the questions he } \\
\text { made } \\
\text { Problem-solving: } \\
\text { Do not execute the steps of the solution } \\
\text { plan. }\end{array}$ & $\begin{array}{l}\text { Evaluation of the results } \\
\text { obtained: } \\
\text { There is no revaluation of the } \\
\text { solution and is not suitable. } \\
\text { New idea (none): } \\
\text { No different from before. }\end{array}$ \\
\hline LND & $\begin{array}{l}\text { Connecting problems based } \\
\text { on biological material he } \\
\text { has learned. An action is } \\
\text { considered good if it serves } \\
\text { to meet their own needs. }\end{array}$ & $\begin{array}{l}\text { Understanding: } \\
\text { Understands what is asked but prioritizes } \\
\text { personal interests } \\
\text { Solution planning: } \\
\text { Not yet able to make questions that fit the } \\
\text { problem he understands } \\
\text { Problem-solving: } \\
\text { Not yet based on the proposed plan that } \\
\text { causes incorrect completion steps. }\end{array}$ & $\begin{array}{l}\text { Evaluation the results obtained: } \\
\text { There is no revaluation of the } \\
\text { solution and is not appropriate. } \\
\text { New idea (none): } \\
\text { No different from before. }\end{array}$ \\
\hline
\end{tabular}

A summary of the characteristics of students' moral development (SU and LND) residing in JPM2B2 is as follows.

\begin{tabular}{|c|c|c|c|}
\hline Characteristics & Positioning & Diversity & Novelty \\
\hline $\mathrm{SU}$ & $\begin{array}{l}\text { Connecting problems based } \\
\text { on biological material he } \\
\text { has learned. His views and } \\
\text { principles of action should } \\
\text { be done for the common } \\
\text { good }\end{array}$ & $\begin{array}{l}\text { Understanding: } \\
\text { Can explain conditions that are asked from } \\
\text { moral dilemmas according to their role } \\
\text { Solution planning: } \\
\text { Thoughts about familiar problems that } \\
\text { have been identified with the same or } \\
\text { similar questions } \\
\text { Problem Solving: } \\
\text { Steps to solve the problems are in } \\
\text { accordance with the common good. }\end{array}$ & $\begin{array}{l}\text { Evaluation of the results } \\
\text { obtained: } \\
\text { The truth and benefits of the } \\
\text { solutions obtained. } \\
\text { New Idea (None): } \\
\text { The solutions made are not } \\
\text { different from before. }\end{array}$ \\
\hline LND & $\begin{array}{l}\text { Connecting problems based } \\
\text { on biological material he } \\
\text { has learned. His views and } \\
\text { principles of action are not } \\
\text { imposing his own will and } \\
\text { mutual respect. }\end{array}$ & $\begin{array}{l}\text { Understanding: } \\
\text { Can explain questions that are asked from } \\
\text { moral dilemmas according to their role } \\
\text { Solution planning: } \\
\text { Focus more on the questions than causes } \\
\text { similarity between the solution and what } \\
\text { was asked. } \\
\text { Problem Solving: } \\
\text { Not yet based on the proposed plan that } \\
\text { causes incorrect completion steps. }\end{array}$ & $\begin{array}{l}\text { Evaluation of the results } \\
\text { obtained: } \\
\text { Has not yet produced a solution } \\
\text { obtained from the previous } \\
\text { problem solving. } \\
\text { New Idea (None): } \\
\text { No solution was found from the } \\
\text { problem solving step. }\end{array}$ \\
\hline
\end{tabular}


A summary of the characteristics of students' moral development (ASW and AR) residing in JPM2B3 is as follows.

\begin{tabular}{|c|c|c|c|}
\hline Characteristics & Positioning & Diversity & Novelty \\
\hline ASW & $\begin{array}{l}\text { Connecting problems based } \\
\text { on biological material he } \\
\text { has learned. The views and } \\
\text { principles of his actions } \\
\text { entrust relationships that } \\
\text { have not been harmonious } \\
\text { and the need to help others. }\end{array}$ & $\begin{array}{l}\text { Understanding: } \\
\text { Can explain conditions that are asked from } \\
\text { moral dilemmas according to their role } \\
\text { Solution Planning: } \\
\text { Reflects on previous actions to achieve } \\
\text { present goodness } \\
\text { Problem Solving: } \\
\text { Prioritizes persistent efforts. }\end{array}$ & $\begin{array}{l}\text { Evaluation of the results } \\
\text { obtained: } \\
\text { Surrender, pray, and tries to } \\
\text { find a solution. } \\
\text { New idea (none): } \\
\text { Prays and tries to get a solution. }\end{array}$ \\
\hline AR & $\begin{array}{l}\text { Connecting problems based } \\
\text { on biological materials he } \\
\text { has learned. His views and } \\
\text { principles of action } \\
\text { emphasize mutual help or } \\
\text { help among others. }\end{array}$ & $\begin{array}{l}\text { Understanding: } \\
\text { Can explain conditions that are asked from } \\
\text { moral dilemmas according to their role } \\
\text { Solution planning: } \\
\text { Reflects on past actions to make a better } \\
\text { future. } \\
\text { Problem-solving: } \\
\text { Based on the proposed plan, each step of } \\
\text { the solution is correct for the safety of } \\
\text { others. }\end{array}$ & $\begin{array}{l}\text { Evaluation of the results } \\
\text { obtained: Regrets the past } \\
\text { mistakes. } \\
\text { New idea (none): } \\
\text { Solutions made are not done } \\
\text { with careful thought. }\end{array}$ \\
\hline
\end{tabular}

A summary of the characteristics of students' moral development (IM and MNM) residing in JPM2B4 is as follows.

\begin{tabular}{|c|c|c|c|}
\hline Characteristics & Positioning & Diversity & Novelty \\
\hline IM & $\begin{array}{l}\text { Connecting problems based } \\
\text { on biological material he } \\
\text { has learned. His views and } \\
\text { principles of actions } \\
\text { emphasize the possibility of } \\
\text { changing the law through } \\
\text { rational considerations on } \\
\text { humanitarian grounds }\end{array}$ & $\begin{array}{l}\text { Understanding: } \\
\text { Conflicting conditions of two human roles. } \\
\text { Solution planning: } \\
\text { Towards religious and noble character and } \\
\text { showing a view of conscience and thinking } \\
\text { about basic human rights. } \\
\text { Problem solving: } \\
\text { The problem proposed is correct with the } \\
\text { belief that the results will be obtained. } \\
\text { Surrenders to the Almighty and ask } \\
\text { forgiveness to those who have been hurt. }\end{array}$ & $\begin{array}{l}\text { Evaluation of the results } \\
\text { obtained: } \\
\text { Gets solution by regretting the } \\
\text { wrong doing that was done and } \\
\text { will always apologize for his } \\
\text { mistakes. } \\
\text { New idea: } \\
\text { Produce noble and } \\
\text { commendable morals in } \\
\text { everyday life. }\end{array}$ \\
\hline MNM & $\begin{array}{l}\text { Connecting problems based } \\
\text { on biological material he } \\
\text { has learned. His views and } \\
\text { principles of action } \\
\text { emphasize caring for the } \\
\text { needs of others. }\end{array}$ & $\begin{array}{l}\text { Understanding: } \\
\text { The conflicting conditions between limited } \\
\text { time and opportunities to make others } \\
\text { happy. } \\
\text { Solution planning: } \\
\text { Always tries to find other alternatives that } \\
\text { reflect from past experiences. } \\
\text { Problem solving: } \\
\text { Based on previous mistakes, makes } \\
\text { improvements to the solution step with the } \\
\text { principle for the common good. }\end{array}$ & $\begin{array}{l}\text { Evaluation of the results } \\
\text { obtained: Regrets any } \\
\text { wrongdoing that has been done } \\
\text { and will always apologize. } \\
\text { New idea: } \\
\text { Determined to be able to give } \\
\text { good to others. }\end{array}$ \\
\hline
\end{tabular}

\subsection{Characteristics of Students' Moral Development at Each Level in Biological Problem Solving}

Characteristics of moral levels in solving biological problems at each level are presented in Table 1. 
Table 1. Characteristics of JPM2B1 on different subjects

\begin{tabular}{|c|c|c|c|}
\hline \multicolumn{2}{|c|}{ Problem identification } & \multicolumn{2}{|c|}{ Solution planning } \\
\hline $1^{\text {st }}$ Subject & $2^{\text {nd }}$ Subject & $1^{\text {st }}$ Subject & $2^{\text {nd }}$ Subject \\
\hline $\begin{array}{l}\text { Task 1: ask the doctor to give } \\
\text { him morphine; so he can } \\
\text { quickly pass away } \\
\text { Task 2: Anas can't call his } \\
\text { father, and he can't remarry }\end{array}$ & $\begin{array}{l}\text { Task 1: the woman herself wants him } \\
\text { to die quickly. } \\
\text { Task 2: Sari should've given the } \\
\text { medicine to her friend who is having } \\
\text { a hard time because her mother has } \\
\text { diarrhea }\end{array}$ & $\begin{array}{l}\text { Task 1: ask the doctor to give } \\
\text { him a lot of morphine, it's } \\
\text { better so he dies quickly. } \\
\text { Task 2: Why does Anas have to } \\
\text { contact someone who is not his } \\
\text { father anymore? }\end{array}$ & $\begin{array}{l}\text { Task 1: Did the doctor give the } \\
\text { medicine to the woman? And } \\
\text { the Doctor considered because } \\
\text { he was dying. } \\
\text { Task 2: let Mirna run home to } \\
\text { give the diarrhea medicine to } \\
\text { her mother }\end{array}$ \\
\hline \multicolumn{4}{|l|}{ Characteristics } \\
\hline $\begin{array}{l}\text { Shows a view that an action is } \\
\text { considered good if it serves to } \\
\text { meet its own needs }\end{array}$ & $\begin{array}{l}\text { Shows a view that an action is } \\
\text { considered good if it serves to meet } \\
\text { their own needs. }\end{array}$ & $\begin{array}{l}\text { Not yet able to make solution } \\
\text { planning out of problems }\end{array}$ & $\begin{array}{l}\text { Able to make solution planning, } \\
\text { but is not in accordance with the } \\
\text { problem identification }\end{array}$ \\
\hline Problem solving & & Evaluation of the results obtained & \\
\hline Male & Female & Male & Female \\
\hline $\begin{array}{l}\text { Task } 1 \text { and Task } 2 \text { is not } \\
\text { corresponding }\end{array}$ & $\begin{array}{llllll}\begin{array}{l}\text { Task } 1 \text { and } \\
\text { corresponding }\end{array} & & & & \\
\end{array}$ & $\begin{array}{l}\text { Task } 1 \text { and Task } 2 \text { is not } \\
\text { corresponding }\end{array}$ & $\begin{array}{l}\text { Task } 1 \text { and Task } 2 \text { is not } \\
\text { corresponding }\end{array}$ \\
\hline \multicolumn{4}{|l|}{ Characteristics } \\
\hline $\begin{array}{l}\text { Not characterized because the } \\
\text { identification and resolution of } \\
\text { the problem made is not } \\
\text { corresponding. }\end{array}$ & $\begin{array}{l}\text { Unable to express the problem } \\
\text { solution due to the difficulty in } \\
\text { connecting between the identification } \\
\text { and the solution plan that was made. }\end{array}$ & $\begin{array}{l}\text { Not characterized because the } \\
\text { identification and resolution of } \\
\text { the problem made is not } \\
\text { corresponding. }\end{array}$ & $\begin{array}{l}\text { Not characterized because the } \\
\text { identification and resolution of } \\
\text { the problem made is not } \\
\text { corresponding. }\end{array}$ \\
\hline
\end{tabular}

Table 2. Characteristics of JPM2B2 based on different subjects

\begin{tabular}{|c|c|c|c|}
\hline \multicolumn{2}{|c|}{ Problem identification } & \multicolumn{2}{|c|}{ Solution planning } \\
\hline 3rd Subject & 4th Subject & 3rd Subject & 4th Subject \\
\hline
\end{tabular}

Task 1: May go to a pharmacy or drugstore, make loans if you need to and promise to pay later; find whatever work can be done because the money is important to pay the medicine.

Task 2: It is better for the doctor to give advice to the woman's family, for them to pray and be patient and not to associate partners with God, they must believe that God will help

\section{Characteristics}

A view to meet the needs of others, and the principle of his actions is based on his experience that must always be pleasant and caring for the needs of others.
Task 1: Mirna should have talked nicely asking for help for her mother's medicine without force; Mirna is her best friend, she should also help a friend who is having problems; Mirna must apologize immediately, and so should Sari for insulting Mirna's family.

Task 2: The doctor may suggest treatment methods other than medical; find traditional treatment or else, it is important to give a try.
Task 1: Mirna can go to Sari first to ask for help, or she has to go to the pharmacy to find the medicine to prevent her mother from getting worse.

Task 2: Ether/morphine is a drug that accelerates death, so it is dangerous if used continuously, and doctors must always advise her
Task 1: Is Sari willing to give the medicine?; Sari shouldn't be angry if she doesn't want to help; Mirna should have asked Sari kindly without force.

Task 2: Is the disease really difficult to cure?; the woman should be patient with her illness; she should not ask the doctor a lot of morphine that speed up death
A view to prioritizing the needs of others, and the principle of his actions is that what he has experienced must always be pleasant and care for the needs of others
A view to meet the needs of others, and the principle of his actions is based on his experience that must always be pleasant and caring for the needs of others.

\begin{tabular}{|c|c|c|c|}
\hline \multicolumn{2}{|c|}{ Problem solving } & \multicolumn{2}{|c|}{ Evaluation of the result obtained } \\
\hline Male & Female & Male & Female \\
\hline
\end{tabular}


Task 1: Mirna has promised to pay the rest so Sari does not need to be angry with Mirna; Sari realized her mistake and apologized to make up their friendship.

Task 2: Should ask a lot of doctor's advice for better health, and I have to try to do the best in anything for

Task 1: I shouldn't reject and get angry; and I asked for the medicine nicely because of Sari

Task 2: Irrelevant, because the characteristic is not being characterized.
Task 1: They must be friends again like before

Task 2: If she uses morphine she may feel calm, but the danger will be worse for hes life, but every problem must have a solution
Task 1: I have to apologize to Mirna; she will quickly die if she stays that way, and do not rush while being angry at Mirna as a friend; and pay attention to the right ethics and don't let the emotions take control

Task 2: irrelevant

myself

Characteristics

The principle of his actions is based on his experience that must always be pleasant by caring for the needs of others.
The principle of his actions is based on his experience that must always be pleasant by caring for the needs of others.
The principle of his actions is based on his experience that must always be pleasant by caring for the needs of others.
The principle of his actions is based on his experience that must always be pleasant by caring for the needs of others.

Table 3. Characteristics of JPM2B3 based on different subjects

\begin{tabular}{|c|c|c|c|}
\hline \multicolumn{2}{|r|}{ Problem identification } & \multicolumn{2}{|c|}{ Solution planning } \\
\hline 5th Subject & 6th Subject & 5th Subject & 6th Subject \\
\hline $\begin{array}{l}\text { Task 1: just donate Anas } \\
\text { blood to his father; it } \\
\text { will save his father's } \\
\text { life; and forgive the } \\
\text { mistakes his father had } \\
\text { made } \\
\text { Task 2: It's ok. But just } \\
\text { for a little; it would be } \\
\text { dangerous later }\end{array}$ & $\begin{array}{l}\text { Task 1: Anas must be able to accept the } \\
\text { situation and not hold grudges, especially the } \\
\text { person in the critical state is his biological } \\
\text { father; and if Anas's father had recovered, he } \\
\text { would have to promise that Anas would be } \\
\text { supported and not distinguished from his other } \\
\text { siblings. Task 2: Sari should help her friend by } \\
\text { giving the medicine; and Mirna must apologize } \\
\text { to Sari for what she did }\end{array}$ & $\begin{array}{l}\text { Task 1: I will forgive and } \\
\text { donate blood to my } \\
\text { father because it's } \\
\text { regarding my father's } \\
\text { life. } \\
\text { Task 2: Is the disease } \\
\text { really difficult to cure?; } \\
\text { the woman should be } \\
\text { patient with her illness; } \\
\text { should not ask the doctor } \\
\text { a lot of morphine to } \\
\text { speed up her death }\end{array}$ & $\begin{array}{l}\text { Task 1: His father realizes the } \\
\text { mistakes he made so far; and } \\
\text { promised to support Anas so that } \\
\text { his life would be better. Task 2: } \\
\text { Mirna snatches the diarrhea } \\
\text { medicine from Sari because she is } \\
\text { forced to heal her mother; and } \\
\text { deliver the diarrhea medicine to her } \\
\text { sick mother }\end{array}$ \\
\hline
\end{tabular}

\begin{tabular}{|c|c|c|c|}
\hline Characteristics & & & \\
\hline $\begin{array}{l}\text { The views and } \\
\text { principles of action are } \\
\text { fulfilling obligations, } \\
\text { obeying the law, and } \\
\text { maintaining the social } \\
\text { order. }\end{array}$ & $\begin{array}{l}\text { A view that prioritizes the needs of others, and } \\
\text { the principle of his actions is based on his } \\
\text { experience that must always be pleasant and } \\
\text { caring for the needs of others. }\end{array}$ & $\begin{array}{l}\text { The views and principles } \\
\text { of action are fulfilling } \\
\text { obligations, obeying the } \\
\text { law, and maintaining } \\
\text { social order }\end{array}$ & $\begin{array}{l}\text { The views and principles of action } \\
\text { are fulfilling obligations, obeying } \\
\text { the law, and maintaining the social } \\
\text { order. }\end{array}$ \\
\hline
\end{tabular}

\begin{tabular}{|c|c|c|c|}
\hline \multicolumn{2}{|r|}{ Problem solving } & \multicolumn{2}{|c|}{ Evaluation of the results obtained } \\
\hline Male & Female & Male & Female \\
\hline $\begin{array}{l}\text { Task 1: Safety of his } \\
\text { father's life takes } \\
\text { precedence; I will give } \\
\text { my blood for my father; } \\
\text { and father must not } \\
\text { force his own will, he } \\
\text { must be patient } \\
\text { Task 2: don't give up; } \\
\text { pray and try; and make } \\
\text { new medicines }\end{array}$ & $\begin{array}{l}\text { Task 1: Safety of his father's life takes } \\
\text { precedence; I will give my blood for my father; } \\
\text { and father must not force his own will, he must } \\
\text { be patient } \\
\text { Task 2: I should give the medicine to Mirna, } \\
\text { because her mother is sick; and Mirna's mother } \\
\text { can be helped and healed so that the problem is } \\
\text { solved }\end{array}$ & $\begin{array}{l}\text { Task 1: I am regretful } \\
\text { and I will apologize; and } \\
\text { I was mistaken because I } \\
\text { had abandoned my child } \\
\text { all this time. } \\
\text { Task 2: pray and give } \\
\text { effort; and don't use } \\
\text { morphine anymore }\end{array}$ & $\begin{array}{l}\text { Task 1: I am regretful and I will } \\
\text { apologize; and I was mistaken } \\
\text { because I had abandoned my child } \\
\text { all this time. } \\
\text { Task 2: pray and give effort; and } \\
\text { don't use morphine anymore }\end{array}$ \\
\hline
\end{tabular}


The views and principles of action are fulfilling obligations, obeying the law, and maintaining social The views and principles of action are fulfilling obligations, obeying the law, and maintaining social order.
The principle of his actions is based on his experience that must always be pleasant by caring for the needs of others.

order.

The principle of his actions is based on his experience that must always be pleasant by caring for the needs of others.

Table 4. Characteristics of JPM2B4 based on different subjects

\begin{tabular}{|c|c|c|c|}
\hline \multicolumn{2}{|c|}{ Problem identification } & \multicolumn{2}{|c|}{ Solution planning } \\
\hline 7th Subject & 8th Subject & 7th Subject & 8th Subject \\
\hline $\begin{array}{l}\text { Task 1: If his father can recover, } \\
\text { Anas can stay with his father; and } \\
\text { he admits all his mistakes and } \\
\text { wants to apologize } \\
\text { Task 2: Can no longer feel the } \\
\text { pain; and requested the doctor to } \\
\text { give him morphine so that he } \\
\text { would die quickly }\end{array}$ & $\begin{array}{l}\text { Task 1: Is still alive and should be } \\
\text { happy again with that little time } \\
\text { remaining; and precisely that } \\
\text { limited time that can make him } \\
\text { happy, and make his family } \\
\text { happy } \\
\text { Task 2: Anas must continue to } \\
\text { help and donate blood, because } \\
\text { an evil is not good if it is } \\
\text { rewarded back with evil deeds }\end{array}$ & $\begin{array}{l}\text { Task 1: I will forgive; donate } \\
\text { blood to my father; and } \\
\text { concerns my father's life } \\
\text { Task 2: He must be patient } \\
\text { with this test with an open } \\
\text { heart and repent to Allah and } \\
\text { ask forgiveness from those } \\
\text { who have been hurt by him }\end{array}$ & $\begin{array}{l}\text { Task 1: Will the doctor give } \\
\text { morphine to the woman?; and the } \\
\text { doctor must continue to try to get } \\
\text { other drugs. The woman must also } \\
\text { continue to try to get other } \\
\text { treatments } \\
\text { Task 2: Even though my father had } \\
\text { behaved in a bad way, after all, he } \\
\text { was my parents who had supported } \\
\text { me }\end{array}$ \\
\hline \multicolumn{4}{|l|}{ Characteristics } \\
\hline $\begin{array}{l}\text { The views and principles of } \\
\text { action emphasize the possibility } \\
\text { of changing the law through } \\
\text { rational considerations on } \\
\text { humanitarian grounds. }\end{array}$ & $\begin{array}{l}\text { The view of moral decisions is } \\
\text { based on conscience, the } \\
\text { universal principle of justice, and } \\
\text { equal fundamental human rights. }\end{array}$ & $\begin{array}{l}\text { The view of moral decisions is } \\
\text { based on conscience, the } \\
\text { universal principle of justice, } \\
\text { and equal fundamental human } \\
\text { rights. }\end{array}$ & $\begin{array}{l}\text { The view of moral decisions is } \\
\text { based on conscience, the universal } \\
\text { principle of justice, and equal } \\
\text { fundamental human rights. }\end{array}$ \\
\hline
\end{tabular}
ights.

\begin{tabular}{cccc}
\hline & Problem solving & & Evaluation of the results obtained \\
\hline Male & & Female & Male \\
\hline
\end{tabular}

Task 1: Donating blood is a noble deed, and will get merit from Allah

Task 2: He must be patient, face this test with an open heart, asking forgiveness from those have been hurt by him
Task 1: I am regretful and I will apologize; and I was mistaken because I had abandoned my child all this time.

Task 2: I will behave like before again; give care and love Anas and do not abandon him again
Task 1: I am regretful and I will apologize; and I was mistaken because I had abandoned my child all this time.

Task 2: pray and give effort; and don't use morphine anymore
Task 1: I will make my family happy and apologize, I will die in peace

Task 2: Even though I was disappointed by my father, I had to help him

\section{Characteristics}

The view of guilt and the measure of moral decisions is based on conscience, the universal principle of justice, and equal fundamental human rights.
The view of moral decisions is based on conscience, the universal principle of justice, and equal fundamental human rights.
The view of moral decisions is based on conscience, the universal principle of justice, and equal fundamental human rights.
The view of moral decisions is based on conscience, the universal principle of justice, and equal fundamental human rights.

\subsection{Other Findings for Each JPM2B}

Based on the written assignments and the results of interviews for each subject, the study obtained the following results:

\section{1) JPM2B1}

a. Subjects tend to be more comfortable in expressing good and bad about moral dilemmas through doing written assignments.

b. Subjects are only able to understand the problem of the role in the discourse of moral dilemmas.

c. Subjects are planning solutions and steps not in accordance with the problem they understand.

d. Mastery of the subject to the material allows the related person links with other explanations in biology. 
2) JPM2B2

a. Subjects find it easy to express which one is good and bad to moral dilemmas through doing written assignments. The statement shows that there are differences in moral development according to the problem compared to JPM2B1.

b. Understanding the problem of both roles in the moral dilemma discourse is appropriate, which shows an increase in moral development in understanding biological problems compared to JPM2B1.

c. The subject makes common questions in different ways.

d. Mastery of the subject of the material allows the related person with other explanations in the material of biological science.

3) JPM2B3

a. Subjects tend to find it difficult when expressing which one is good and bad to moral dilemmas in doing written assignments.

b. Subjects have difficulty in positioning themselves into two different roles in communicating their thinking, personality, and problem-solving behavior.

c. The challenge encountered is due to the unfamiliar second role, so the prediction of answers is quite varied.

d. Some solutions are related to steps in biological material, and some are not, in everyday life.

4) JPM2B4

a. Subjects tend to feel difficult when expressing which one is good and bad of moral dilemmas in carrying out written assignments, indicating the existence of differences in moral development.

b. Subjects have difficulty in positioning themselves into two different roles in communicating their thinking, personality, and problem-solving behavior.

c. The teacher in biological science has never given the task of solving the moral dilemma problem that has been done.

d. Subjects received the ability to link with steps other than biological material, namely religious material.

\section{Discussion}

\subsection{Level of Moral Development in Biological Problems}

The feasibility of the level of moral development and written assignments developed is determined based on the evaluation of JPM2B's hypothetical theory, written tasks by experts and practitioners, and readability of written assignments by students.

1) JPM2B Hypothetical Theory.

The hypothetical JPM2B theory developed by researchers is a theory related to the level of moral development of Piaget, Kohlberg, and Hoffman. Based on these three theories and linked to Polya's (1973) problem-solving theory, a fundamental theory (theoretical formulation), which was called the level of moral development in biology, was found.

Based on the results of the validation carried out by experts, the overall average results obtained for this JPM2B based on the expert validation test amounted to 4.61 with a correct category, while for reliability earned $96.31 \%$. The result means that levels and theories are in line with the expression, as well as the way of thinking of researchers to construct the level can be accepted. The validity of the contents and constructs of the theory is sufficient so that they can be implemented and verified in the field.

\section{2) Written Assignments}

Based on the results of the validation carried out by experts, the overall average results obtained for this written assignment based on the expert validation test were 4.81 , with the category of very valid and reliability of $98.13 \%$.

The results of this assessment indicate that the written assignments arranged theoretically are very valid, meaning that written assignments are following the mindset of researchers to construct written assignments that are acceptable. It means that the content and construct validity of the theory is sufficient so that it can be implemented and verified in the field.

\subsection{Comparison of Students' Moral Development Divisions in Biological Problem Solving}

The characteristics of even-numbered subjects in this study appear in the lower category than odd-numbered 
subjects in producing novelty. It is suspected that the subject is taken in the growing category of adolescents because he was only 13 years old. According to Berndt (in Santrock, 2007), at the age of 13-15 years, adolescents show signs of developing a problem-solving style that is more free from the peer or parental influence. Research conducted by Leventhal (Santrock, 2007) shows support for Berndt's discovery, namely that the influence on peers increases in early adolescence (13-15 years).

There are similarity characteristics that appear at each level of JPM2B1, JPM2B2, and JPM2B3. The similarity that arises is in terms of positioning the primary role of the written task discourse undertaken. But in JPM2B4 compared to the previous JPM2B, there were "differences" in terms of subjects making new expressions made on male subjects. These differences illustrate the characteristics for each hierarchy, where the higher the level, the subject's ability to solve moral-based biological problems increases.

\subsection{Characteristics of Students' Moral Development at Each Level in Resolving Biological Problems}

The steps to plan solutions and solve problems on all subjects at all levels show arguments that are practically easier to remember and know than conceptually. The practical case is easy to remember, for example, using material excerpts contained in the moral dilemma discourse or quoted information about the problem or what is known. Whereas conceptual arguments are easy, for example, using materials learned in previous biological science learning that are remembered correctly.

The subjects in JPM2B4 have been able to use action-based arguments from their experience of learning biology in class, which comes from their sincere belief in the greatness and power of Allah. The analysis shows that the subject's moral development tends to gain empathy used to evaluate interpersonal dilemmas. The result means that the characteristics of JPM2B obtained are compatible with the level of moral development proposed by Piaget, Kohlberg, and Hoffman. The result shows that gender differences are found in moral emotion and cognition (Nunner-Winkler et al., 2007; Malti \& Buchmann, 2010; Eisenberg et al., 2014). These differences may be the result of gaps in social expectations, directing children to express more caring feelings in behavior than boys (Hastings, McShane, Parker, \& Ladha, 2007).

According to Kurtines and Gerwitz (1991), the process of forming moral actions or behaviors involves four important stages. (1) Interpreting the situation to understand and discover what actions are possible to do and how they affect the overall problem. (2) Describe what is important to do by applying moral values to a particular situation to establish moral behavior. (3) Choosing among moral values to decide what to do. And (4) taking actions following moral values.

Meanwhile, in terms of the ability to solve problems from the moral dilemma in biology, it shows that subjects at all JPM2B levels have demonstrated the ability to understand issues. Some subjects demonstrate the ability to plan solutions, resolve problems, and re-assess problem-solving. The result has fulfilled the Polya model step in solving biological problems. It shows that problem-solving is one of the most important abilities and needs to be developed in junior high biological science learning. This discovery is supported by the statement of the Ministry of National Education (2010); problem-solving is the process of applying previously acquired knowledge to new unknown situations. According to Duong (2012), problem-solving is the art of thinking in its purest form. In the classroom, problem-solving is best used to help students understand complex ethical dilemmas, think about the future, or do strategic planning.

\subsection{Other Findings for Each JPM2B Level in Resolving Biological Problems}

Based on the written assignments and the results of interviews of the research subjects, the following findings were obtained.

1) The highest level (JPM2B4) to the lowest level (JPM2B1) of subjects have reached the positioning indicators. The result shows that students have been able to use their thinking skills and help students understand a dilemma. Muhson (2007) states that the goal of problem-solving is to instill in students how to think systematically and logically in overcoming a problem at hand.

2) Characteristics of moral development obtained tend to increase along with the JPM2B level they occupy. The result shows that the ability to solve problems related to one's moral consequences generally varies according to differences in personality, way of thinking, and behavior (Ma-Kellams \& Blascovich, 2013; Huitt, 1992; Myszkowski \& Storme, 2012; Huszczo \& Endres, 2013 ). Similarly, Sarbaini (2011) states that the conflict of moral values will encourage the occurrence of thought processes, stimulate changes, and the development of cognitive structures of children towards the future self-positioning and problem-solving.

3) Mastery of the subject in all JPM2B over the biological material allows other relevant relatable explanations in the materials in biology. This is in accordance with the statement of Suyanto (2010), that there are several 
strategies that can be applied to create a learning system that develops the nation's morals through biology. Including by using the problems of Indonesian people's lives such as poverty, disease, food shortages and malnutrition, population growth height, environmental pollution, forest destruction, flora and fauna extinction, and so on.

4) Subjects tend to feel easy to difficult when expressing which one is deemed as good and bad to the moral dilemma in doing written assignments. The difficulty is due to the role in the unfamiliar dilemma, so the prediction of answers is quite varied. This is following Ibrahim's (2003) statement, that the problem-solving model leads students to the many procedures used to organize knowledge and draw conclusions.

5) The discovery of the ability to associate with biology materials shows novelty in noble morals and religious content. Duong (2012) states that, problem-solving is a thought that is directly directed to find a solution to a specific problem.

\section{Conclusion}

Based on the results of research and discussion, it can be concluded that the formulation of valid and reliable classifications and identification of students' moral development in solving biological problems (JPM2B), as follows:

1) JPM2B1 is a good act judged by the views and principles of its actions to fill its obligations and needs regardless of the needs of others, can formulate problems, and plan problem solving according to their role based on biological material. Students tend to declare solving problems quickly because the teacher has taught them, but cannot solve diverse problems, and there are no new expressions.

2) JPM2B2 is a good act judged by the views and principles of its actions for the common good and mutual respect. When positioning and planning solutions, they consistently link problem-solving plans based on the biological material they have learned and can explain according to their respective roles. They can make questions in different ways, but the completion step only repeats the previous explanation, and there is no new expression.

3) JPM2B3 is a good act judged by the view of mutual help between each other to create a better future. When positioning and planning for solutions, they consistently link with biological materials they had learned. Students find it challenging to do the settlement and review the problem solving again due to unfamiliarity in the other role. Still, the answers are quite varied, and the steps are correct in various ways. They still repeat the previous explanation, and there are no new expressions.

4) JPM2B4 is a good act judged by the view of caring for the needs of others, emphasizing rational considerations for humanitarian reasons and God's blessing. When positioning and planning a solution, they consistently link to the biological material they had learned. Students find it challenging to do the settlement and see the problem again due to unfamiliar roles, but the answers are quite varied, the steps are correct in various ways. They tend to change plans with humanitarian considerations, according to the needs of the person involved. They have novel ideas, the desire to give good to others, noble and praiseworthy in everyday life.

\section{References}

BNSP. (2006). Permendiknas RI No. 22 Tahun 2006 tentang Standar Isi untuk Satuan Pendidikan Dasar dan Menengah. Jakarta.

Budiningsih, C. A. (2008). Pembelajaran Moral. Berpijak pada Karakteristik Siswa dan Budayanya. Jakarta. PT. Rineka Cipta.

Dewiyani. (2010). Profil Proses Berpikir Mahasiswa dalam Memecahkan Masalah Matematika berdasarkan Penggolongan Tipe Kepribadian dan Gender. Disertasi Doktor pada Program S3 Pendidikan Matematika Universitas Negeri Surabaya. Tidak dipublikasikan.

Duong, M-Q. (2012). A Comparison of the Effects of Curriculum Learning Experiences on Problem-Solving Efficacy between the University of Science and the University of Social Sciences and Humanities Students. SOSIOHUMANIKA Jurnal Pendidikan Sains Sosial dan Kemanusiaan, 5(2).

Eisenberg, N., Spinrad, T. L., \& Morris, A. (2014). Empathy-related responding in children. In J. G. Smetana, \& M. Killen (Eds.), Handbook of moral development (2nd ed., pp. 184-207). New York: Psychology Press.

Foshay, R., \& Kirkley, J. (2003). Principles for teaching problem solving. Technical Paper \#4. Indiana University. Plato Learning, Inc.

Fraenkel, J. R. (1977). How To Teach About Values: An Analytic Approach. Prentice-Hall, Inc.Englewood Cliff. New Jersey. 
Hastings, P. D., McShane, K. E., Parker, R., \& Ladha, F. (2007). Ready to make nice: parental socialization of young sons' and daughters' prosocial behaviors with peers. The Journal of Genetic Psychology, 168(2), 177-200. https://doi.org/10.3200/GNTP.168.2.177-200

Huitt, W. (1992). Problem Solving and Decision Making: Consideration of Individual Differences Using the Myers-Briggs Type Indicator. Journal of Psychological Type, 24, 33-44.

Huszczo, G., \& Endres, M. (2013). Joint Effects of Gender and Personality on Choice of Happiness Strategies. Europe's Journal of Psychology, 9(1), 136-149. https://doi.org/10.5964/ejop.v9i1.536

Ibrahim, M. (2003). Model Pemecahan Masalah dalam Pembelajaran Biologi. Dalam Susilo, Herawati. 2003. Kapita Selekta Pembelajaran Biologi. Jakarta: Pusat Penerbitan Universitas Terbuka.

Kurtines, W. M., \& Gewirtz, J. L. (1991). Handbook of Moral Behavior and Development: Research (1st ed., Volume 2). Publisher: Psychology Press.

Lind, G. (2005). Dilemma Discussion Revisited-The Konstanz Method. Europe's Journal of Psychology, 1(1). https://doi.org/10.5964/ejop.v1i1.345

Ma-Kellams, C., \& Blascovich, J. (2013). Does Science Make You Moral? The Effects of Priming Science on Moral Judgments and Behavior. PLoS ONE, 8(3), e57989. https://doi.org/10.1371/journal.pone.0057989

Malti, T., \& Buchmann, M. (2010). Socialization and individual antecedents of adolescents' and young adults' moral motivation. Journal of Youth and Adolescence, 39(2), 138-149. https://doi.org/10.1007/s10964-009-9400-5

Ministry of National Education. (2010). Learning Based on Mathematical Problems in Elementary Schools. High Quality Programming Mathematics Elementary Module. Director General of PMPTK. P4TK Mathematics 2010.

Muhson, A. (2007). Penerapan Metode Problem Solving dalam Pembelajaran Statistik Lanjut. Diunduh 27 Desember 2012 dari. https://doi.org/10.21831/jep.v6i1.591

Myszkowski, N., \& Storme, M. (2012). How Personality Traits Predict Design-Driven Consumer Choices. Europe's Journal of Psychology, 8(4), 641-650. https://doi.org/10.5964/ejop.v8i4.523

Nunner-Winkler, G., Meyer-Nikele, M., \& Wohlrab, D. (2007). Gender differences in moral motivation. Merrill-Palmer Quarterly-Journal of Developmental Psychology, 53(1), 26-52. https://doi.org/10.1353/mpq.2007.0003

Perry, D. (2009). Instructional Strategies Online. Retrieved from http://olc.spsd.sk.ca/de/pd/instr/index.html

Piaget, J., \& Inhelder, B. (2010). The Psychology of the Child. Basic Books. New York.

Polya, G. (1973). How to Solve It. A New Aspect of Mathematical Method (2nd ed.). Stanford University. Princeton University Press. Princeton, New Jersey.

Santrock, J. W. (2007). Child Development (11th ed.). The McGraw-Hill Companies, Inc.

Sarbaini. (2011). Model Pembelajaran Berbasis Kognitif Moral (dari Teori ke Aplikasi). Universitas Lambung Mangkurat. Laboratorium PPKn.

Slavin, R. E. (2009). Educational Psychology: Theory and Practice (9th ed.). Pearson Education, Inc. Upper Saddler River. New Jersey.

Suyanto, S. (2010). Building the National Character Through Biology Education. Prosiding Seminar Nasional Biologi 3 Juli 2010 "Biologi dan Pengembangan Profesi Pendidik Biologi".

Tillman, F. A., \& Cassone, D. (2012). A Professional's Guide to Decision Science and problem Solving. An Integrated Approach for Assessing Issues, Finding Solutions, and Reaching Corporate Objectives. Pearson Education, Inc. Publishing as FT Press Upper Saddle River, New Jersey 07458.

Upton, P. (2012). Psychology Express: Development Psychology. Pearson Education Limited.

Welch, P. (2011). Moral Psychology and the Problem of Moral Criteria. Journal of Moral Education, 40(4), 513-526. https://doi.org/10.1080/03057240.2011.618779

Widodo, M., \& Jatiningsih, O. (2013). Peran Single Mother dalam Mengembangkan Moralitas Anak di Kelurahan Wonokromo Kecamatan Wonokromo Surabaya. E-Journal Kajian Moral dan Kewarganegaraan, $1(1)$.

Zubaedi. (2011). Desain Pendidikan Karakter: Konsepsi dan Aplikasinya dalam Lembaga Pendidikan. Jakarta: 
Kencana Prenada Media Group.

Zuriah, N. (2011). Pendidikan Moral \& Budi Pekerti dalam Perspektif Perubahan. Menggagas Platform Pendidikan Budi Pekerti secara Konstektual dan Futuristik. Jakarta: PT. Bumi Aksara.

\section{Copyrights}

Copyright for this article is retained by the author(s), with first publication rights granted to the journal.

This is an open-access article distributed under the terms and conditions of the Creative Commons Attribution license (http://creativecommons.org/licenses/by/4.0/). 